\title{
6. Engaging Citizens in Co-producing Service Outcomes
}

\begin{abstract}
John Alford
Much of this volume concerns the involvement of citizens in deciding what to do or how to do it, principally through what I call the 'co's' - consultation, co-deliberation and co-design. The assumption is that a particular service will be delivered to citizens by government. Co-production, the subject of this chapter, takes the process further by having citizens take part in producing the service. This is a fundamental difference, and it is gaining popularity among governments around the world. On balance, I think that this is a good thing.

I find, however, that alongside this flourishing interest in the idea of coproduction exist many myths; each of the key issues in co-production has its own misconception to shadow it. In this chapter I will address both the issues and the misconceptions that surround co-production in tandem. The issues to be addressed offer a road map of what I shall talk about, focusing on the following five key questions: What is co-production? What do we mean by citizens? How do we identify potential co-producers? When should co-production be utilised? How can co-production be elicited from citizens? Each of these questions is shadowed by a misconception, which I will address later in the chapter.

What is co-production? The popular understanding of this concept is that it concerns joint deliberation or consultation - in other words, citizens being involved in deciding what to do or how to do something as well as producing it. This is a loose usage of the term, however, leading to its indiscriminate employment. The word production is not used to include deciding what to do, so why use the word co-production to include co-deciding what to do? Coproduction is about doing something, not about deciding what to do. That is not to say that co-decision is not important. But it is something different from co-production. Nor is it to say that, when co-productive processes are taking place, there isn't a lot of co-deliberation happening alongside it. What I want to do is to analytically distinguish co-production as a term.

There are a number of considerations in defining the term. When there is a service to be provided, there are three possible scenarios: it could be provided by a government organisation acting alone, by an external party acting alone, or, it could be achieved jointly between them. The other thing that marks the distinction between deciding what to do and actually doing it is that, strictly speaking, co-production is the process of something being undertaken jointly by a government organisation and an external party.
\end{abstract}


It's never that simple, however. There are some activities, like planning and design, for example, with their emphasis on the activity that is to be coproduced, which lie in a grey area between co-production and co-decision. Examples of such crossover can be found in architecture or town planning.

Further than that, there are activities undertaken by private parties - be they companies, individuals or whatever - that have no apparent connection with government. Their involvement arises because of government influence, and I think we need to acknowledge this phenomenon - what I call 'nudged production' or 'self-service', following Richard Thaler and Cass Sunstein (2008). An example of this technique is the way in which a driver will slow down at an intersection because of the presence of a roundabout. To an extent, the driver is being nudged by the government to slow down, thereby contributing to the public purpose of reducing the road toll.

In other words, co-production is not only something that is undertaken jointly, but also things that are prompted by some action, behaviour or incentive provided by a government agency. This can include planning and design, but, certainly, the real focus is on actually doing it.

The second term to define is citizen. What do we mean by this? There can be a failure to distinguish between different faces of a citizen - a point that is raised by Lynelle Briggs (Chapter 7). It is important to acknowledge that citizens are, first and foremost, always part of the collective 'we' who: contribute to determining what government should do through all the processes of democracy enjoyed in Australia, benefit from the public value that governments create and, who have various rights and responsibilities associated with both of those things.

Above all, therefore, we are all citizens, but I want to argue that we have multiple other roles in which we can function as co-producers. Firstly, we are also clients: we can be both a citizen and a client. As citizens we interact with government in terms of public value while, as clients, we interact with services that might provide some private value. In fact, often our enjoyment of the private value contributes to public value in the process - when school pupils get an education, for example, that is good for them as individuals in their life prospects, but it's also good for the wider society that citizens are literate, numerate and knowledgeable in the myriad ways provided by an education.

Students at state school are examples of beneficiary clients - people who receive services but don't pay money for them, even though they are receiving what we might call 'private value'. A second group are what we might call 'obligatees' or 'regulatees' - that is, people who are subjected to obligations by government agencies. This also affects their private value, often negatively, 
and we impose obligations on people on behalf of the society at large, through which the individual is disadvantaged for the sake of the public at large. These are different kinds of interactions than those between the government and the collective citizenry.

In fact, co-production can give an additional, vital reason for governments to pay attention to their clients. In their 1992 book, Reinventing Government: How the Entrepreneurial Spirit is Transforming the Public Sector, David Osborne and Ted Gaebler argue that government organisations are hopeless at client service because they don't get any money from their clients, and therefore have no incentive to provide good service. I would argue there is another incentive: while clients don't contribute money, they can contribute co-productive effort if the relationship is properly managed. Clients are more likely to do that if government agencies try to understand what it is that they want, and try to give it to them - which is essentially client focus.

Citizens can also be people who make voluntary contributions, outside of service encounters with government. Formal volunteering involves working for a government department or a not-for-profit or community organisation examples include the Country Fire Service or Meals on Wheels. But volunteering may also involve random acts of sociability and helpfulness in the community. These acts contribute something to the community as a whole, even if they are not organised through the formal channels of government or non-profit community organisations.

When I refer to citizens in this chapter, therefore, I exclusively refer to beneficiary clients, obligatees-regulatees and volunteers.

This leads me to the next question: how do we identify potential co-producers? The answer to this question provides the basis for challenging another misconception about co-production which, with due deference to Eliza Doolittle and the play My Fair Lady, I call the 'wouldn't it be loverly' misconception. This describes the view that co-production is a new thing which would be nice to have. In fact, my research shows that in many, and probably most areas of public sector work, co-production is already an established reality.

Let me explain by way of an example. Think of a fire brigade in output terms: that its purpose is to put out fires quickly and efficiently. This is the general view we have of the work of fire brigades. But the process of putting out a fire is, in fact, far more complex. To illustrate this point, imagine the various processes at work, from when a house catches fire. Before the blaze can be put out, a core 'production process' must take place. First 000 might be called, following which a dispatcher sends a fire truck, which speeds to the fire; the fire is then hosed with water. 
What this highlights is a core production process. Once 000 has been called, most of the work is done internally by the fire brigade; thus we're talking so far about the internal production of desired outputs. But, when you start to think about the work of a fire brigade, it becomes clear that these internal processes rely on processes performed by external parties, which I call co-productive contributions. For a start, external parties like neighbours or property owners and occupants ring 000 - or more generally. to install smoke alarms. The functioning of 000 , and of the fire despatcher, relies on maintenance contractors keeping telecoms up to date. Next the fire engine needs to be ready to go, which relies on regular servicing by mechanics. For the fire engine to speed to the fire, the streets need to be accessible, for which the road authorities are responsible. And finally, to hose the fire with water there needs to be a fire hydrant a responsibility of the relevant water corporation. What we have unearthed, therefore, is that there are two types of contributors to the output of a fire brigade. Firstly, there are the internal contributors - the clients and staff that work inside the fire brigade. But there are also the external co-producers, such as the people who make slippery poles or keep the roads drivable. A fire brigade relies on contributions of time and effort by external factors.

So far we've only been considering the purpose of a fire brigade framed in output terms, but when we go further and frame it in outcome terms - namely, to minimise the fire damage to life, property and the environment - we find that co-production is an even bigger part of the picture. What's more, this broader outcome can be achieved in a variety of ways in addition to the output of the fire brigade. Firstly, it is more likely to happen if there is timely evacuation from the burning house - which is, in turn, more likely if the owner or occupant has a fire response plan. A positive outcome is also more likely if the fire occurs but has less impact on the house - something which largely depends on whether the house was built to resist fire (and whether the property owner did the right thing in terms of building requirements), another function of the owners and occupants.

This example shows that, when it comes to the outcome terms of a fire brigade, the property owner or occupant - i.e., the nearest thing the fire brigade has to a client - has to do some work to ensure that the purpose of the brigade is achieved. The potential contributors to the outcome, be they property owners or roads authorities, do more than just call 000 and sit back and wait for the service to be delivered to them; they play an active part in reducing the damage that fires might inflict.

Outcome focus also changes the nature of the work done by the fire brigade itself. Not only are they engaged in delivering their important service of putting out fires, they are also seeking to induce others to contribute to their ultimate purpose of reducing harm from fires; for example, by educating the community 
on fire safety through school visits and other such endeavours. In addition to this education component, technical advice is provided to building owners and occupiers about ensuring the minimisation of fire damage. They all play a role in contributing to this outcome. So, the fire brigade is in the business not only of delivering services but also of influencing others.

This relates to the 'wouldn't it be loverly syndrome' that I mentioned earlier, because it shows that co-production is not just something that it would be nice to have. In fact, it's already happening in the normal functioning of many public services. My research suggests that most public services entail at least some element of co-production, and I think this resonates with the point Don Kettl (Chapter 3) raises about naming a problem that can't be confined to one organisation when you start to look at it seriously. In a sense we've been coproducing all our lives without knowing it.

This leads to my next question: when should co-production be utilised? It also raises what I call the 'exploitation misconception' - that co-production is about government getting citizens to shoulder the cost of service delivery. The answer to the question of when co-production should be utilised depends on the particular characteristics of the case at hand. On one hand co-production is not the answer to all the problems known to humankind. On the other, it's not something to be dismissed out of hand every time it is raised. Instead, whether to utilise co-production depends on the circumstances.

As Kettl points out, there is no one-size-fits-all use for co-production; the context determines its suitability. Sometimes co-production is not an effective tool of government, especially when it is ill thought-out, maybe unnecessary and has not involved a process of meaningful consultation and participation in decision-making by citizens. Such cases usually occur when governments have orchestrated co-production for cosmetic purposes or other superficial reasons. If, however, there is more public value coming from people doing things in a particular way, and those individuals who are doing those things are themselves gaining more value, then the endeavour is worthwhile - a valuable exchange.

What then, are these circumstances? The first of them is what I call interdependency, which is where value cannot be created without some contribution from an external party. In other words, the internal process is bound up with the external process. In that situation, the question is not whether to co-produce but rather how best to utilise the co-production.

Such reforms have been evident in programs for the unemployed, with or without mutual obligation. They involve seeking to get the unemployed to take steps to find work; it can be difficult for an employment agency to get someone into a job unless the unemployed improve their suitability by training, searching 
for jobs, making a favourable impression on an employer and maintaining that impression (for at least three months, so that they count in the success story statistics). It is also apparent, for example, in health, child protection, conservation and road safety.

The second circumstance is where the services are substitutable and value can be achieved by either the organisation or by the external party; that is, they are substitutes for each other. And here the issue is which party can do it better or cheaper? Similarly with the debate over whether or not to outsource a particular service, the question is whether it is delivered more successfully in house, or by an outside provider. This is where the exploitation myth comes in, and where it's also, in my view, refuted. Some advocates of citizen co-production focus on its potential to reduce the size and therefore the costs of government - I think David Cameron's so-called 'Big Society' has a whiff of that about it - that it will be achieved by handing over some of the burden to citizens.

But the weight of the available research indicates that co-production is better for enhancing value rather than reducing costs. In other words, for a given level of costs you can get a better outcome, rather than having the same outcome for less cost. I would argue, and I think the research supports this, that the exploitation of citizen co-producers doesn't usually work, and this has to do with the nature of the reasons why citizens co-produce, to which we now turn.

How can co-production be elicited from citizens? This question raises what I call the 'motivation misconception', and there are two distinct, but simplistic, schools of thought on this issue. One school argues that citizens will only co-produce when it's in their self-interest do so - to get monetary reward or avoid sanctions. The other school argues that citizens will co-produce if they are stirred by altruism. But the reasons for citizens engaging in co-production are more complex than either self-interest or altruism. In fact, co-productive behaviours by external parties stem from two factors. One is their willingness to co-produce, but the other is their ability to do so, and these are in turn prompted, at least partly, by things the organisation does to or for or with them, which I call 'motivators' or 'facilitators.' These can be framed in various ways (John et al. 2011).

Our willingness to co-produce usually stems from a mixture of motivators, and these can be divided into material and non-material factors. The motivators of material self-interest are sanctions - such as punishment, pain, deprivation of liberty, financial loss — or material reward — such as money, health or amenity. While these are important, they are not the sole reasons why people co-produce. Also affecting people's propensity to co-produce are non-material motivations: intrinsic interest, sense of social belonging or desire to avoid disapproval, and identification with the purpose of the organisation or program — or the 'mission alignment' of the external party with the organisation's purpose. 
These non-material motivations cannot be reduced simply to altruism. Economists sometimes talk of either self-interest or altruism influencing behaviour, but, in fact, I think these motivations are more complex than that. Consider the following example of a case of mission alignment in which someone joins the military because of national pride. Now, national pride can be a good thing or a bad thing, depending on how it's used, but it is definitely a larger motivator than our own self-interest. The propensity of individuals to enlist in the military is partly a function of how justifiable they think the war is that they're being asked to fight. These non-material motivations interact with material self-interest in various ways to encourage, if not coerce or manipulate, people to co-produce.

The propensity to co-produce is not simply a matter of willingness but also of the individual's ability to do so. Two options arise in situations in which people feel unable to perform a particular task: change the task or change the people. Changing the task might mean simplifying it so as to enable the individual to be more capable of completing it; for example, by introducing a simple, single digit number (000) rather than a multi-digit one. The other approach is to make the citizen more capable of doing a task; for example, through the use fire drills or job-search training.

Eliciting co-production from citizens can only work if it amounts to a valuecreating social exchange, in which the government receives co-productive effort by citizens and the citizen receives some mix of material and non-material rewards. Both parties should get more than they give. This is a social rather than an economic exchange because it involves diffuse and differed dealings among multiple parties - not immediate quid pro quo transactions among the buyers and sellers in the market. Those who have read the literature on social exchange, or Robert Titmuss' book, The Gift Relationship (1970) will be familiar with this.

In short, citizen co-producers are not Pavlovian respondents to carrots and sticks. If they are willing to contribute time and effort to organisational purposes, they do so for their own good reasons, which are only partially influenced by the motivators and facilitators that are offered by government.

In conclusion, co-production is not just a nice idea - it is already embedded in public activities. The question is one of making the best of it, not whether we should do it. Nor is co-production about getting citizens to do work that should be done by government; whether co-production should be used at all depends on the circumstances. And finally, in closing, citizens produce for their own good reasons, which can be only partially influenced. 
Putting Citizens First

\section{References}

John, P., Cotterill, S., Moseley, A., Richardson, L., Smith, G., Stoker, G., and Wales, C. 2011. Nudge, Nudge, Think, Think: Using experiments to change civic behaviour. London: Bloomsbury Academic.

Osborne, D., and Gaebler, T. 1992. Reinventing Government: How the entrepreneurial spirit is transforming the public sector. Reading: Addison Wesley.

Thaler, R.H. and Sunstein, C.R. 2008. Nudge: Improving decisions about health, wealth and happiness. New Haven: Yale University Press.

Titmuss, R. 1970. The Gift Relationship. London: Allen \& Unwin. 